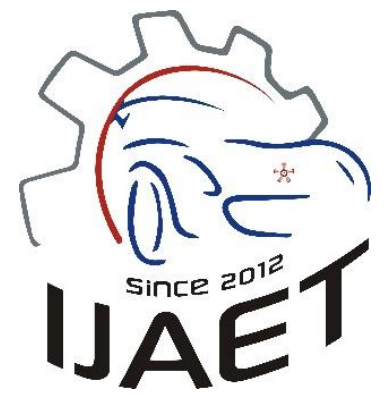

e-ISSN: 2146 - 9067

International Journal of Automotive

Engineering and Technologies

journal homepage: http://ijaet.academicpaper.org

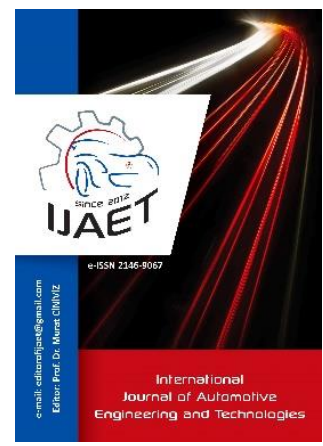

Original Research Article

\title{
The Pyrolytic Fuel Production From Nutshell-Rice Husk Blends and Determination of Engine Performance and Exhaust Emissions in a Direct Injection Diesel Engine
}

\author{
Fatih Aksoy ${ }^{1}$, Ahmet Uyumaz $^{2}$, İbrahim Mutlu ${ }^{1}$, Furkan Akbulut ${ }^{1}$, Emre Y$_{1} 1 m a z^{3}$ \\ ${ }^{1}$ Afyon Kocatepe University, Faculty of Technology, Automotive Engineering Department, 13200, Afyon / TURKEY \\ ${ }^{2}$ Mehmet Akif Ersoy University, High Vocational School of Technical Sciences, 15100 Burdur / TURKEY \\ ${ }^{3}$ Gazi University, Faculty of Technology, Automotive Engineering Department, 06500, Ankara/TURKEY
}

\begin{abstract}
ARTICLE INFO
* Corresponding author auyumaz@mehmetakif.edu.tr

Received: November 06, 2018

Accepted: December 16, 2018

Published by Editorial Board Members of IJAET

(C) This article is distributed by Turk Journal Park System under the CC 4.0 terms and conditions.
\end{abstract}

\begin{abstract}
In this study, pyrolytic fuel from nutshell and rice husk blends was produced at $500^{\circ} \mathrm{C}$ temperature, $1 \mathrm{~L} / \mathrm{min}$ gas flow rate and $10{ }^{\circ} \mathrm{C} / \mathrm{min}$ heating rate. Pyrolytic fuel was experimented in a single cylinder, direct injection diesel engine with different engine speeds of 1750, 2000, 2250, 2750, $3000 \mathrm{rpm}$ at wide open throttle. The blend of 10\% pyrolytic fuel and 90\% diesel (B10) and pure diesel were selected as test fuel. Test results showed that conversion efficiency increased with $15 \%$ rice husk and $85 \%$ nutshell blends compared to pure nutshell at $500^{\circ} \mathrm{C}$ temperature, $10^{\circ} \mathrm{C} / \mathrm{min}$ and $1 \mathrm{~L} / \mathrm{min}$ gas flow speed. In addition, power output and brake torque decreased $10.20 \%$ with B10 compared to diesel. Specific fuel consumption (SFC) increased $28.42 \%$ with B10 compared to diesel. HC and CO reduced with pyrolytic fuel about $43.87 \%$ and $15.72 \%$ compared to diesel respectively. As a result, similar properties were seen between pyrolytic fuel and diesel. So, it was found that pyrolytic fuel could be efficiently used in diesel engines without detailed modification.

Keywords: Biodiesel, Optimization, Nutshell, Engine Performance, Exhaust Emission
\end{abstract}

\section{Introduction}

Fossil fuels have been mostly used in spark ignition and compression ignition engines nowadays. Fossil fuels are generally natural gases or petroleum products. Gasoline and diesel fuels are utilized in transportation sector [1].

Recently, researchers and manufacturers have directed to find alternative energy sources due to increasing of oil prices and imbalance of global oil market. In addition, fossil fuels have undesirable effects on land, air and water.
Climate change can negatively affect people [2]. Combustion of fossil fuels caused to release various greenhouse gases such as carbon dioxide, nitrogen oxides and other toxic and volatile compounds. It was determined that carbon dioxide increased by about 10.65 billion tones due to usage of fossil fuels [3]. Researches on alternative energy have increased owing to consumed fossil fuel sources, environmental concerns and political addiction. UN climate panel aimed to reduce greenhouse gases by about $50-80 \%$ until 2050. It is essential to get rid of fossil fuels addiction in order to achieve this 
goal [4]. The usage of alternative and renewable energy resources (wind, geothermal, hydroelectric, biomass) have become the main topic of conversation due to mentioned issues. Among these resources, biomass has been considered as alternative energy resource and it is important as raw material. It helps to reduce $\mathrm{CO}_{2}$ emissions [5]. Biomass is one of the available, alternative energy resource that meets huge energy demand for both rural and urban areas. Bioenergy meets $10 \%$ of global energy demand and it is known as the biggest renewable energy resource [6]. International energy agency (IEA) has predicted that bioenergy significantly contributes to low carbon global energy systems in road transport, aviation, transportation and industry sectors in the future [7].

Biofuels are liquid or gas that is produced from biomass in order to obtain energy. Biofuels have been considered as environmentally friendly fuel since they have low carbon content and emit low $\mathrm{SO}_{2}, \mathrm{NO}_{\mathrm{x}}$ and soot emissions [8]. The percentage of the usage of biofuels in transportation is by about $2 \%$. Furthermore, it is aimed to reach $9 \%$ with the developed new technologies and methods until 2030. It also contributes to the energy security and on socialeconomic improvement apart from the reduction of greenhouse gases [9]. Gasification, combustion and pyrolysis are the commonly used methods for converting biomass into the of energy forms. Pyrolysis is a thermochemical process that is relatively performed at high temperatures in an oxygen-free environment with low humidity. Raw materials for pyrolysis should be ground into fine pieces in order to obtain higher thermal efficiency [10]. Pyrolysis that is one of the biomass conversion methods, is preferred since it is easily applied and production can be carried out at desired conditions. Pyrolytic fuels can be easily carried and stored. It has been determined that pyrolytic fuels release lower greenhouse gases and emissions compared to fossil fuels [11]. Pyrolysis process is performed in the presence of inert gas $\left(\mathrm{N}_{2}\right.$ or Ar) and in the absence of oxygen that reduces environmental pollution because of low gas emissions. This process is convenient for re-use of industrial and agricultural wastes. Efficiencies of obtained products are dependent on the pyrolysis process conditions such as biomass type, particle size, processing temperature, inert gas flow rate for baring [12].

Nutshell has been utilized as valuable and high calorie fuel (4100-4400 cal/gr) in our country especially in the regions where hazelnut is produced. In our country, about 600,000 tons' hazelnut production has been performed in a year. If it is considered that $50 \%$ percentage of produced hazelnut is nutshell, about 300.000 tons' nutshell is obtained in a year [13].

In this study, nutshell was used in order to produce pyrolytic fuel with pyrolysis method. There is no enough study related to pyrolytic fuel production and determination engine performance. There is a knowledge gap in this research field. The main objective of the current study is to increase fuel conversion efficiency in the biodiesel production and observe the engine performance and exhaust emissions. Hence, the effects of temperature on fuel efficiency at constant gas flow and heating rates were experimentally investigated. Rice husk was also added into the nutshell at specific rates $(5 \%$, $10 \%, 15 \%, 20 \%$ ) and the effects on conversion efficiency were researched. The variations of brake torque, power output, $\mathrm{SFC}, \mathrm{CO}, \mathrm{HC}, \mathrm{NO}$ and soot emissions were experimentally investigated in a diesel engine fueled with the blends of $10 \%$ pyrolytic fuel and $90 \%$ pure diesel by vol.

\section{Material and Method \\ 2.1. Pyrolysis process and fuel properties}

Pyrolysis is thermal degradation process in the absence of oxygen [14]. Biomass is decomposed thermally in the atmosphere where the oxygen is absent in the pyrolysis process. The pyrolysis is a highly complex process involving very different reactions. Volatile biomolecules of biomass are decomposed due to heating of biomass and pyrolytic fuel is obtained after condensation. Pyrolysis process is schematically shown in Figure 1.

Nutshell used in the experiments was supplied from a commercial firm. Nutshells are divided into small pieces for the usage in experiments. Pyrolysis device can be able to run between 100 and $550{ }^{\circ} \mathrm{C}$ temperature with the heating speed range of $1-10^{\circ} \mathrm{C} / \mathrm{min}$. It has also reservoir that can involve $1000 \mathrm{~g}$ sample. Pyrolysis device is seen in Figure 2.

The experiments were conducted at $500^{\circ} \mathrm{C}$ 
temperature, $1 \mathrm{~L} / \mathrm{min}$ gas flow rate and 10 ${ }^{\circ} \mathrm{C} / \mathrm{min}$ heating rate. Fuels were produced from $85 \%$ hazelnut and $15 \%$ rice husk. Table 1 shows the properties of produced fuels.

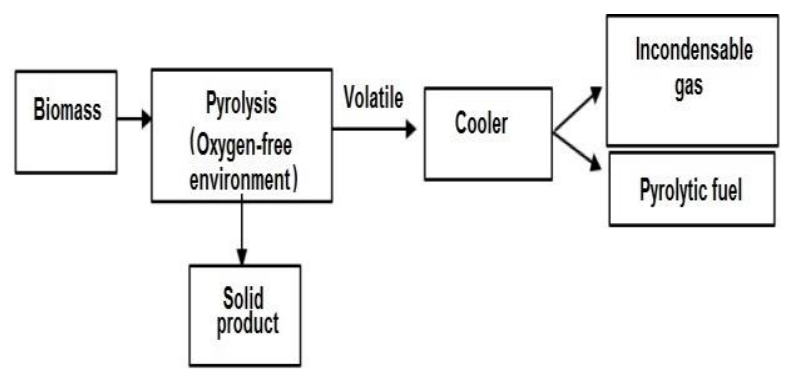

Figure 1. Schematically view of pyrolysis process

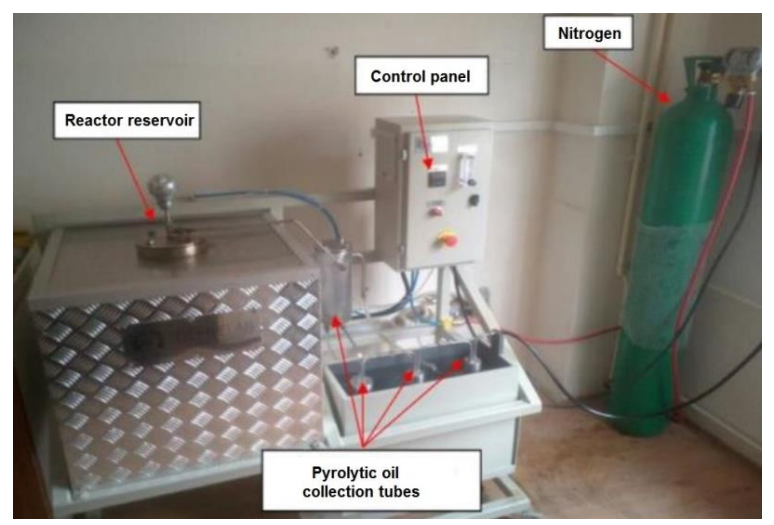

Figure 2. Pyrolysis device

Table 1. Comparison of produced pyrolytic fuel with

\begin{tabular}{lcc}
\multicolumn{3}{c}{ diesel fuel } \\
\hline Properties & B 10 & Diesel \\
\hline Density $\left(\mathrm{g} / \mathrm{cm}^{3)}\right.$ & 0.84168 & 0.83033 \\
Sulphur $(\mathrm{ppm})$ & 90.5 & 7 \\
Water $(\mathrm{ppm})$ & 248.25 & 35.44 \\
Copper strip & $1 \mathrm{a}$ & $1 \mathrm{a}$ \\
Viscosity $\left(\mathrm{mm}^{2} / \mathrm{s}\right)$ & - & 2.7 \\
\hline
\end{tabular}

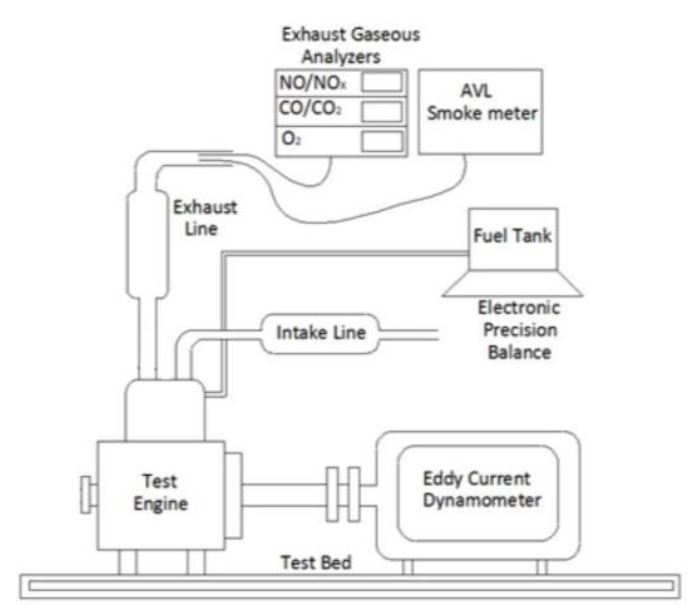

Figure 3. Schematically view of the experimental setup

\subsection{Engine test bed}

Engine performance and exhaust emissions values were determined in the experiments. The test engine was run at wide open throttle and different engine speeds of 1750, 2000, 2250,
2750, $3000 \mathrm{rpm}$. DC dynamometer was used in order to load test engine. Brake torques, fuel consumption, exhaust emissions were measured and recorded. The schematically view of the experimental setup is shown in Figure 3.

Cussons P8160 DC dynamometer was used in the experiments. Dynamometer can absorb 10 $\mathrm{kW}$ engine power at $4000 \mathrm{rpm}$. Dynamometer can also be operated as motor. Engine load was being varied with strain-gauge load cell placed on dynamometer. Engine speed also can be changed with a potentiometer mounted on dynamometer control panel. A single cylinder, four stroke, air cooled, normally aspirated, direct injection Antor 6LD400 diesel engine was used in the experiments. Technical specifications of the test engine are seen in Table 2.

\begin{tabular}{lc}
\multicolumn{2}{c}{ Table 2. Technical specifications of the test engine } \\
\hline Model & Antor 6LD400 \\
Engine type & DI, Diesel \\
Cylinder number & 1 \\
Bore (mm) & 86 \\
Stroke & 68 \\
Swept volume $\left(\mathrm{m}^{3}\right)$ & 395 \\
Compression ratio & $18: 1$ \\
Maximum engine speed & 3600 \\
$\begin{array}{l}\text { Power output }(\mathrm{kW}) \\
\text { Brake torque }(\mathrm{Nm})\end{array}$ & 5.4 @ 3000 rpm \\
Number of injector and & $19.6 @ 2200 \mathrm{rpm}$ \\
holes & $4 \mathrm{x} 0.24$ \\
$\begin{array}{l}\text { Exhaust valve opening } \\
\text { timing }\end{array}$ & $21^{\circ} \mathrm{CA} \mathrm{BBDC}$ \\
$\begin{array}{l}\text { Exhaust valve closing } \\
\text { timing }\end{array}$ & $3^{\circ} \mathrm{CA}$ ATDC \\
\hline
\end{tabular}

Table 3. The technical specifications of Bosch BEA 350 model emission analyzer

\begin{tabular}{|c|c|c|}
\hline Measurement & Operating range & Accuracy \\
\hline $\mathrm{CO}_{2,} \% \mathrm{v} / \mathrm{v}$ & $0-18$ & 0.01 \\
\hline $\mathrm{CO}, \% \mathrm{v} / \mathrm{v}$ & $0-10$ & 0.001 \\
\hline $\mathrm{HC}, \mathrm{ppm}$ & $0-9999$ & $1 \mathrm{ppm}$ \\
\hline NO, ppm & $0-5000$ & $1 \mathrm{ppm}$ \\
\hline Soot, $\%$ & $0-100$ & 0.1 \\
\hline
\end{tabular}

Table 4. The technical properties of AVL DiSmoke 4000 opacimeter

\begin{tabular}{|c|c|c|}
\hline Analyzer & \multicolumn{2}{|c|}{ AVL DiSmoke 4000} \\
\hline \multirow[t]{2}{*}{ Measurement method } & \multicolumn{2}{|c|}{ Partial flow } \\
\hline & Opacity & $\mathrm{K}$ value \\
\hline Operating range & $0-100 \%$ & $\begin{array}{l}\text { Accuracy } \\
0.1 \%\end{array}$ \\
\hline Accuracy $\left[\mathrm{m}^{-1}\right]$ & $0-99.99$ & 0.01 \\
\hline
\end{tabular}

Bosch BEA 350 model emission analyzer was used in order to measure $\mathrm{CO}, \mathrm{CO}_{2}, \mathrm{HC}$, $\mathrm{NO}$ emissions. The technical specifications of 
exhaust gas analyzer are seen in Table 3. The technical properties of AVL DiSmoke 4000 opacimeter are seen in Table 4.

\section{Results and Discussion}

The variations of brake torque versus engine speed are seen in Figure 4. Maximum brake torque was measured at $2200 \mathrm{rpm}$ with the usage of diesel and B10. Higher brake torque was obtained with diesel by about $8.86 \%$ compared to B10. Lower brake torque was obtained with B10 due to calorific value. At $2200 \mathrm{rpm}$, the most charge mixture is delivered into the cylinder in a cycle. So, the highest brake torque was obtained at $2200 \mathrm{rpm}$. After $2200 \mathrm{rpm}$, gas leakages and heat losses increase with the increase of engine speed. Hence brake torque decreased. In addition, higher density of B10 caused to poor injection characteristics resulting in worse homogeneity of charge mixture. This situation deteriorated oxidation reactions.

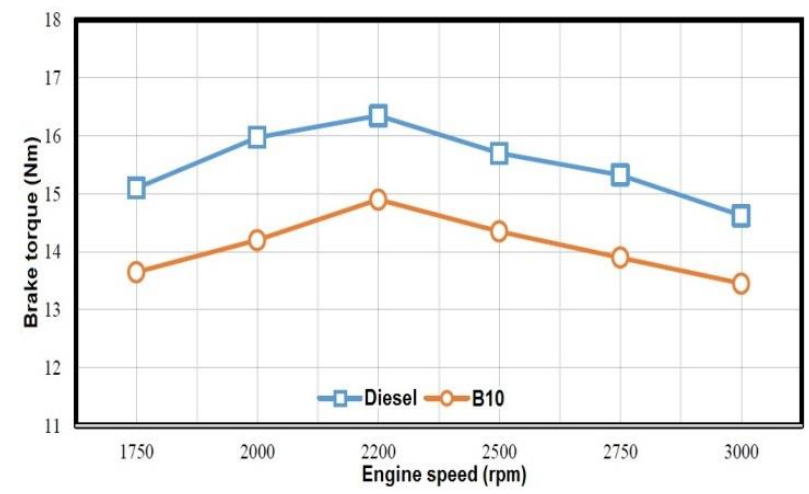

Figure 4. The variations of brake torque with diesel and B10 test fuels

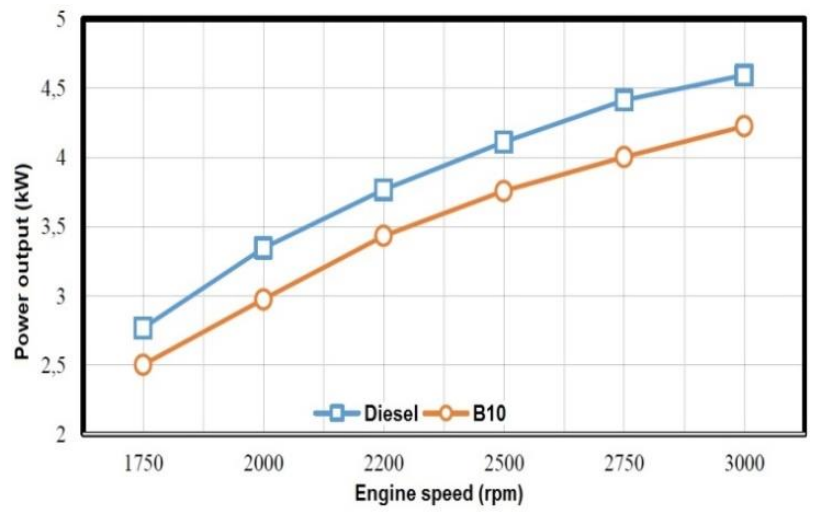

Figure 5. The variations of power output with diesel and B10 test fuels

Figure 5 shows the variations of power output versus engine speed. Maximum power output was obtained at $3000 \mathrm{rpm}$ for both test fuels. Power output was determined as $4.59 \mathrm{~kW}$ and $4.22 \mathrm{~kW}$ with diesel and B10 respectively. Heat energy decreases with B10 owing to lower calorific value resulting in lower power output. It was found that brake torque and power output decreased with the usage of pyrolytic fuel. It can be explained that calorific value of pyrolytic fuels is lower than diesel. So, lower performance values were obtained with pyrolytic fuels. Ignition delay increases with pyrolytic fuels. Hence power output and brake torque decrease [15]. The variations of SFC are seen in Figure 6. SFC decreased until a certain value and then started to increase with the increase of engine speed. Minimum SFC was determined at $2500 \mathrm{rpm}$ for all test fuels. SFC increased about $27.64 \%$ with B10 compared to diesel at this engine speed. It can be also implied that higher fuel should be ignited in order to obtain same power with B10 compared to diesel. It causes to increase SFC with B10. Higher density of pyrolytic fuel caused to inject more fuel, because fuel particle size is getting bigger with B10 compared to diesel. So, injected fuel increases by mass with B10.

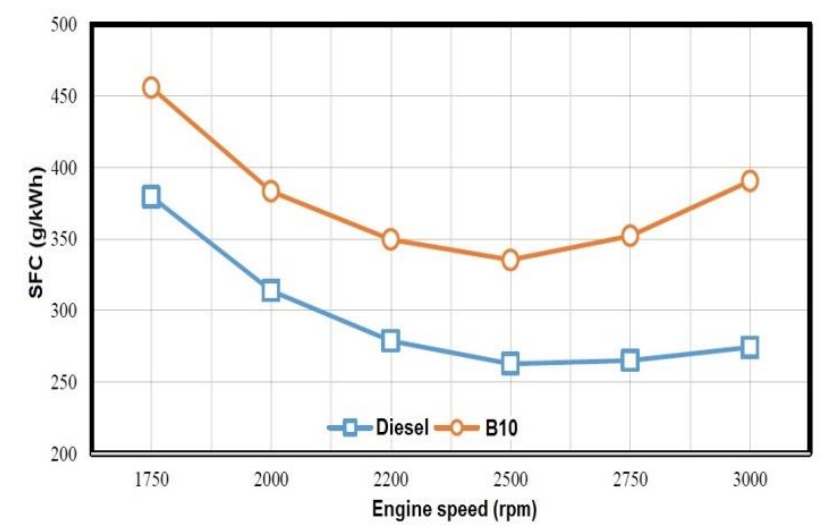

Figure 6. The variations of SFC with diesel and B10 test fuels

It can be mentioned that there is an inverse relationship between calorific value and SFC in the internal combustion engines. The calorific value of test fuel should be higher enough for lower SFC. Lower SFC and higher thermal efficiency are obtained with the increase engine speed, because gas leakages and heat losses decrease towards to partial engine load. Lower mechanical losses are observed between 2500 and $2750 \mathrm{rpm}$ engine speed [16]. The water and oxygen additive content of pyrolytic fuel decreased the calorific value of pyrolytic fuel. This phenomena resulted in higher SFC and the same brake torque with fuel blends compared to pure diesel fuel. Moreover, higher density and 
viscosity of pyrolytic fuel caused to poor injection characteristics, incomplete combustion and higher fuel consumption [17].

Figure 7 depicts the variations of soot emissions versus engine speed. Soot emission increases at higher engine speed. Minimum soot emissions were measured at $1750 \mathrm{rpm}$ for both test fuels. Soot emission reduced $21.91 \%$ with B10 compared to diesel at $1750 \mathrm{rpm}$.

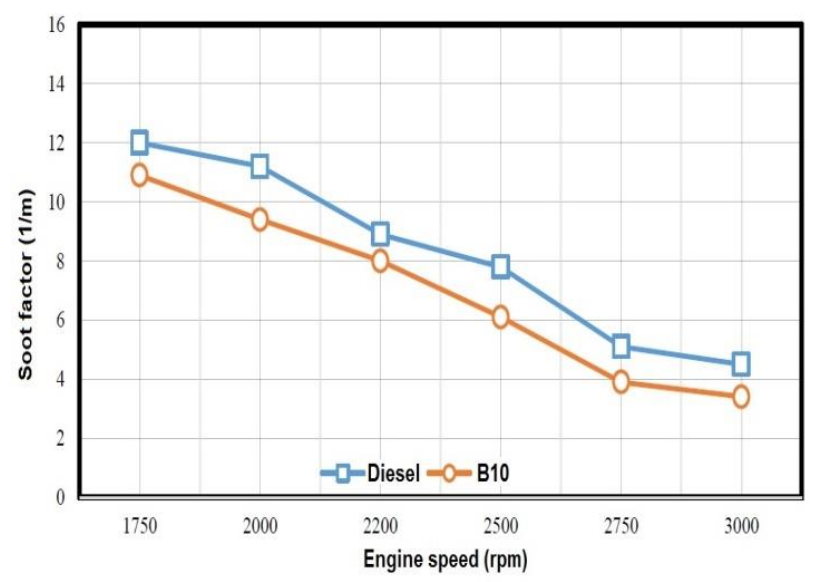

Figure 7. The variations of soot emissions with diesel and B10 test fuels

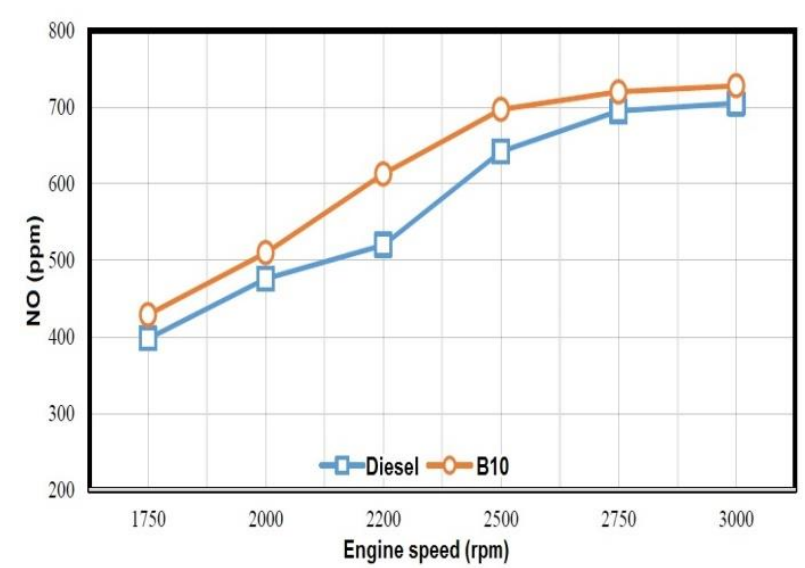

Figure 8. The effects of B10 and diesel fuels on NO formation versus engine speed

Soot emission is released due to poor oxidation of fuel molecules. When the fuel is injected into the combustion chamber, $\mathrm{H}_{2}$ molecules involving in chemical structure of fuel could be rapidly reacted with $\mathrm{O}_{2}$ molecules in the cylinder. If unburned $\mathrm{HC}$ molecules remaining in the combustion chamber could not meet with $\mathrm{O}_{2}$ molecules, soot particle is formed. Oxidation rate should be increased by the existence of oxygen molecules in combustion regions in the cylinder that is the main reason of the reduction of soot emission. Furthermore, lower soot emissions are obtained with pyrolytic fuel due to lower content of aromatic compounds [18]. Figure 8 shows the effects of B10 and diesel fuels on NO formation versus engine speed. Minimum NO formation was observed at 1750 rpm. NO increased $7.78 \%$ with B10 compared to diesel at this engine speed. NO emissions are released at higher combustion temperature during combustion. Oxygen and nitrogen molecules are reacted at high combustion temperature resulting in NO formation.

Nitrogen oxide reacts with ozone in the atmosphere via ultraviolet light from the sun and nitrogen dioxide is produced. Among these harmful gases, nitrogen oxide is one of the most pollutant gas in our lifecycle. Hydrocarbon compounds are decomposed and they are released as $\mathrm{NO}$ and $\mathrm{NO}_{\mathrm{x}} .90 \%$ of $\mathrm{NO}$ is formed dependent on hydrocarbon compounds. Temperature and oxygen fraction are two main factors that affect the NO formation. Combustion temperature decreases and NO emissions increase with the usage of pyrolytic fuels due to higher water content involving in pyrolytic fuels [19]. The variations of HC emissions versus engine speed are seen in Figure 9. HC increased until $2500 \mathrm{rpm}$ engine speed for both test fuels and then started to decrease after this engine speed. HC reduced $6.93 \%$ with B10 compared to diesel at 2500 rpm.

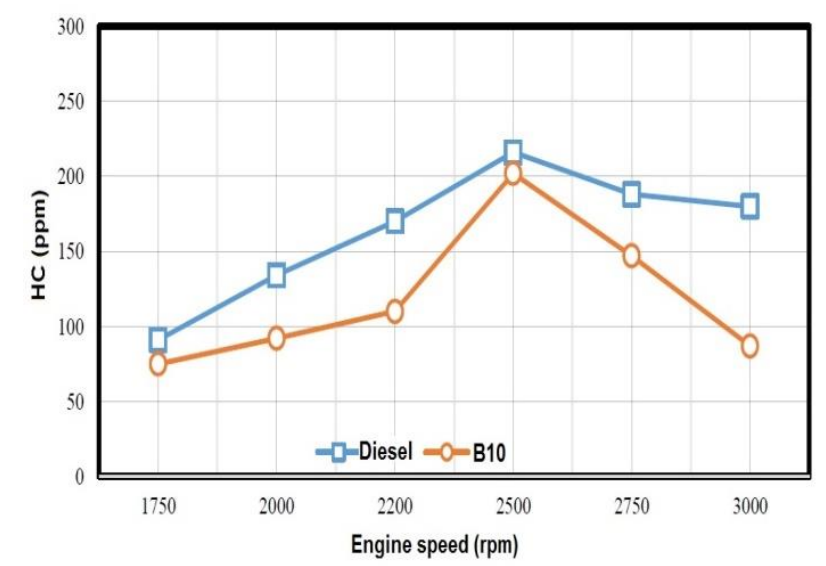

Figure 9. The variations of $\mathrm{HC}$ emissions with diesel and B10 test fuels

$\mathrm{HC}$ is produced because of incomplete combustion due to low temperature and insufficient oxygen. It was seen that $\mathrm{HC}$ increased until $2500 \mathrm{rpm}$ and then started to decrease. Lower $\mathrm{HC}$ was measured with pyrolytic fuels at low engine speeds owing to homogeneity and higher oxygen content of pyrolytic fuels. HC increased in the combustion chamber, because higher fuel molecules are delivered into the cylinder at higher engine 
speeds [20]. On the other hand, injected fuel can be properly diffused in the combustion chamber and gaseous hydrocarbons could not be ignited on the cooler cylinder wall. So, HC increased. However, HC reduced with pyrolytic fuels, because combustion region was small and narrow [21]. The variations of $\mathrm{CO}$ emissions with diesel and B10 are seen in Figure 10. It was found that maximum $\mathrm{CO}$ was measured at low engine speeds in the experiments. But, $\mathrm{CO}$ reduced with the increase of engine speed. $\mathrm{CO}$ reduced $15.72 \%$ with $\mathrm{B} 10$ compared to diesel. Minimum $\mathrm{CO}$ was measured at $3000 \mathrm{rpm}$ for both fuels.

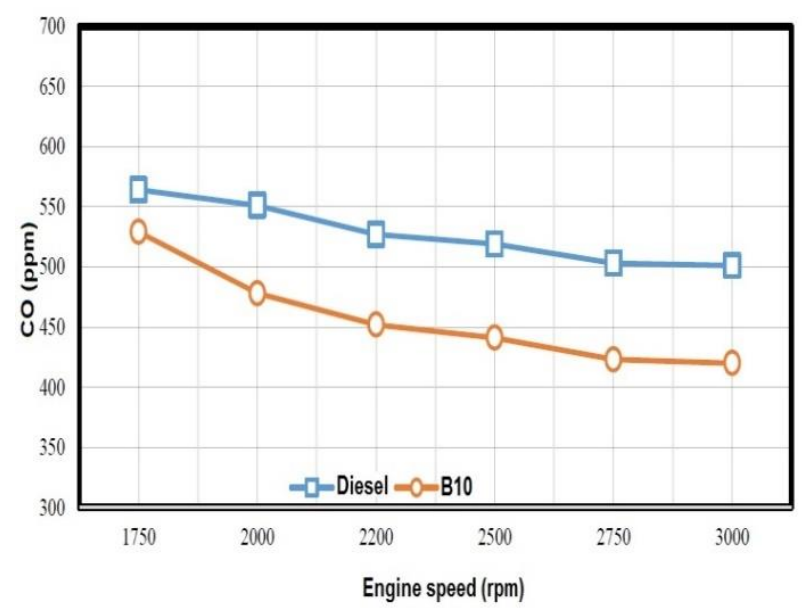

Figure 10. The variations of $\mathrm{CO}$ emissions with diesel and B10 test fuels

CO can be defined as loss chemical energy that could not be utilized in the engine. The main reason of $\mathrm{CO}$ emission release is low air-fuel ratio. $\mathrm{CO}$ is formed to $\mathrm{CO}_{2}$ in case of complete combustion. Combustion could not be completed well due to insufficient oxygen in air/fuel mixture and low exhaust gas temperature. Thus, $\mathrm{CO}$ is formed [22]. $\mathrm{CO}$ is generally reduced at high engine speeds and loads. At low engine speeds, $\mathrm{CO}$ is converted to the $\mathrm{CO}_{2}$. Oxidized carbons caused to release higher amount of $\mathrm{CO}_{2}$ [23].

Combustion efficiency is improved with pyrolytic fuels compared diesel, because they have higher oxygen content. Fuel molecules need sufficient oxygen for complete combustion in the combustion chamber. Since oxygen molecules are abundant during combustion, all fuel molecules can easily participate combustion reactions. Combustion efficiency is dependent on combustion temperature. So, combustion temperature increases at the end of combustion due to sufficient oxygen that chemical oxidation reactions improve. Similarly, combustion efficiency improves. CO reduced because of smaller combustion regions [24]. Another reason is that second atomization is observed via vaporizing water droplet involving in pyrolytic fuel molecules. So, fuel particle can be properly mixed with air. Consequently, lower $\mathrm{CO}$ is formed [25]. Figure 11 shows the variations of $\mathrm{CO}_{2}$ with diesel and $\mathrm{B} 10$ test fuels. Minimum $\mathrm{CO}_{2}$ was measured at $1750 \mathrm{rpm}$ for both fuels. $\mathrm{CO}_{2}$ increased $23.05 \%$ with $\mathrm{B} 10$ compared to diesel. $\mathrm{CO}_{2}$ is released due to complete combustion. $\mathrm{CO}_{2}$ is colorless, odour-free and harmless gas. Since, carbon and hydrogen are disintegrated at the end of combustion, hydrogen is converted to water. If carbon compound meets with sufficient oxygen, it is converted to $\mathrm{CO}_{2}$ [26]. $\mathrm{CO}_{2}$ is complete combustion product that carbon molecules could be well oxidized. There is linear relationship between $\mathrm{B} 10$ and $\mathrm{CO}_{2}$ increase. Because, carbon ratio of pyrolytic fuel $(\mathrm{C}: \mathrm{H}=$ $10.34)$ is higher than diesel $(\mathrm{C}: \mathrm{H}=6.47)$. More carbon molecules were oxidized and higher $\mathrm{CO}_{2}$ was released at the end of combustion [27].

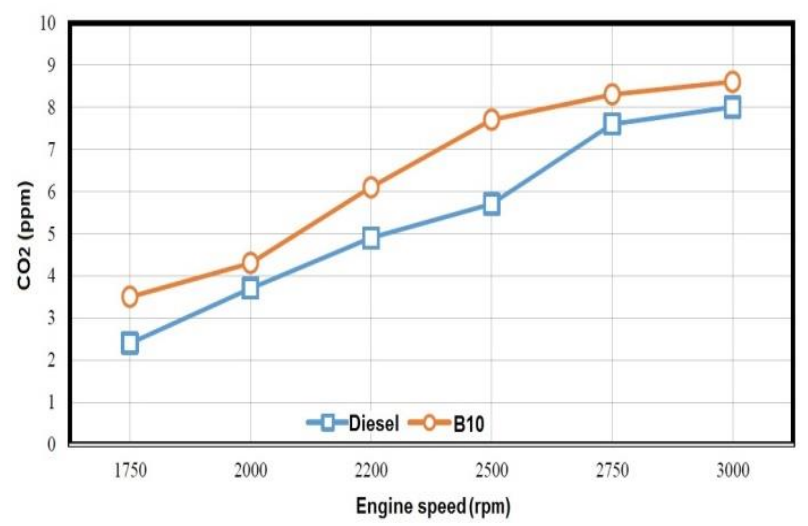

Figure 11. The variations of $\mathrm{CO}_{2}$ emissions with diesel and $\mathrm{B} 10$ test fuels

\section{Conclusions}

In this study, pyrolytic fuel production was performed from nutshells with pyrolysis method. The effects of temperature and rice husk addition on efficiency were investigated and the physical properties of produced pyrolytic fuel were determined. The effects of diesel and B10 test fuels were also investigated on engine performance and exhaust emissions in a single cylinder, direct injection diesel engine. Conversion efficiency was determined as $11.74 \%$ in pyrolysis process of pure nutshell at 
$500^{\circ} \mathrm{C}$ temperature, $10^{\circ} \mathrm{C} / \mathrm{min}$ and $1 \mathrm{~L} / \mathrm{min}$ gas flow speed. On the other hand, conversion efficiency was determined as $21.73 \%$ in pyrolysis process of $15 \%$ rice husk and $85 \%$ nutshell blends at the same conditions. Fuel efficiency increased by about $85.09 \%$ with the addition of $15 \%$ rice husk. It is considered that the increase of fuel efficiency is dependent on silicium compound involving in rice husk. Since fuel injectors are clogged with the usage of B10 fuel blends, SPAN80 was added in the experiments. More homogeneous charge mixture was obtained. Experiments were conducted after SPAN 80 was added.

The variations of engine performance and exhaust emissions can be drawn as following.

- Power output and brake torque decreased about $10.20 \%$ with B10 compared to diesel.

- SFC increased $28.42 \%$ with B10 compared to diesel.

- $\quad$ HC reduced $43.87 \%$ with B10 compared to diesel.

- $\mathrm{CO}$ reduced by about $15.72 \%$ with the usage of pyrolytic fuel compared to diesel.

- It was observed that $\mathrm{CO}_{2}$ increased $23.05 \%$ with pyrolytic fuel compared to diesel.

Researches related to alternative fuels have focused on increase of engine performance, decreasing fuel consumption and exhaust emissions with environmentally friendly fuels. As a result, it was found that the characteristics of pyrolytic fuel obtained from nutshell and rice husk blends are similar to diesel.

\section{Nomenclature}

$\begin{array}{ll}\text { ATDC } & \text { After top dead center } \\ \text { BBDC } & \text { Before bottom dead center } \\ \mathrm{CO} & \text { Carbon monoxide } \\ \mathrm{CO}_{2} & \text { Carbon dioxide } \\ \mathrm{DI} & \text { Direct injection } \\ \mathrm{HC} & \text { Hydrocarbon } \\ \mathrm{IEA} & \text { International Energy Agency } \\ \mathrm{NO}_{\mathrm{x}} & \text { Nitrogen oxides } \\ \mathrm{SFC}_{\mathrm{SO}_{2}} & \text { Specific fuel consumption } \\ \mathrm{UN} & \text { Sulphur dioxide }\end{array}$

\section{References}

1. Doğan O., Atık taşıt lastiğinden üretilen pirolitik yakıtın bir dizel motorda kullanımının deneysel olarak araştırılması, Doktora Tezi, Karabük Üniversitesi, Fen Bilimleri Enstitüsü, Karabük, (2012).

2. Morris, S., Environmental effect of fossil fuels, Energy and the Environment Cost Benefit Analysis, (1975), June (Atlanta, Georgia, U.S.A.).

3. Matsakas, L., Gao, Q., Jansson, S., Rova, U., Christakopoulos, P., Green conversion of municipal solid wastes into fuels and chemicals, Electron. J. Biotechnol. 26:69-83, (2017).

4. Dhyani, V., Bhaskar, T., A comprehensive review on the pyrolysis of lignocellulosic biomass. Renewable Energy. 129: 695-716, (2018).

5. Nagy, T., Mizsey, P., Effect of fossil fuels on the parameters of $\mathrm{CO}_{2}$ capture, Environ. Sci. Technol. 47: 8948-8954, (2013).

6. Choi, M.K., Park, H.C., Choi, H.S., Comprehensive evaluation of various pyrolysis reaction mechanisms for pyrolysis process simulation. Chemical Engineering and Processing - Process Intensification. 130: 19-35, (2018).

7. Bioenergy and biofuels; International Energy Agency (IEA). 〈http://www.iea.org/topics/renewables/bioenerg y/> (Acessed on 2 February 2018).

8. Stöcker, M., Biofuels and biomass-toliquid fuels in the biorefinery: catalytic conversion of lignocellulosic biomass using porous materials. Angewandte Chemie. 47:9200-9211, (2008).

9. Li, M., Xu, J., Xie, H., Wang, Y., Transport biofuels technological paradigm based conversion approaches towards a bioelectric energy framework. Energy Conversion and Management. 172:554-566, (2018).

10. Chen, Z., Wang, M., Jiang, E., Wang, D., Zhang, K., Ren, Y., Jiang, Y., Pyrolysis of Torrefied Biomass. Trends in Biotechnology, 36,12, 1287-1298, (2018).

11. Alagu, R.M., Sundaram, E.G., Preparation and characterization of pyrolytic oil through pyrolysis of neem seed and study of performance, combustion and emission characteristics in CI engine, Journal of the Energy Institute, 91:100-109, (2018). 
12. David, E., Kopac, J., Pyrolysis of rapeseed oil cake in a fixed bed reactor to produce bio-oil, Journal of Analytical and Applied Pyrolysis. 134:495-502, (2018).

13. Bozoğlu, M., The Situation of the Hazelnut Sector in Turkey, International Society for Horticultural Science, DOI:10.17660/ActaHortic.2005.686.85， 686, 641-648, (2005).

14. Czajczyńska, D.,Anguilano, L., H.GhazalR.KrzyżyńskaA.J.ReynoldscN.Spenc er H.Jouhara, Potential of pyrolysis processes in the waste management sector,Thermal Science and Engineering Progress Volume 3, 171-197, (2017).

15. Lee, S., Yoshida, K., Yoshikawa, K., Application of waste plastic pyrolysis oil in a direct injection diesel engine: for a small scale non-grid electrification. Energy and Environment Research; 5:1. (2014).

16. Martinez, J.D., Fernandez, J.R., Valdepeñas, J.S., Murillo, R., Garcia, T., Performance and emissions of an automotive diesel engine using a tire pyrolysis liquid blend. Fuel, 115: 490-499 (2014).

17. Wang, W., Bai, C., Lin, C., Prakash, S. Alternative fuel produced from thermal pyrolysis of waste tires and its use in a DI diesel engine. Applied Thermal Engineering, 93:330338, (2016).

18. Şen, S., Hayvansal yağlardan biyodizel üretimi ve dizel motor performans ve emisyonlarına etkisinin araştırılması. Yüksek Lisans Tezi. Karabük Üniversitesi Fen Bilimleri Enstitüsü. Karabük, (2012).

19. Prakash, R., Singh, R.K., Murugan, S. Performance and emission studies in a diesel engine using bio oil-diesel blends. 2nd International Conference on Environmental Science and Technology, Singapore, (2011).

20. Anup, T.J., Watwe, V. Waste plastic pyrolysis oil as alternative for si and ci engines, International Journal of Innovative Research in Science, Engineering and Technology, 3:7, (2014).

21. Murugan, S., Ramaswamy, M.C., Nagarajan, G., Performance, emission and combustion studies of a DI diesel engine using Distilled Tyre pyrolysis oil-diesel blends. Fuel Processing Technology. 89: 152-159, (2008).

22. Sel, Ö.F. Atık biyodizel kullanılan bir motorda yakıt katkısının performans ve emisyonlarına etkisi. Yüksek Lisans Tezi. Karabük Üniversitesi, Fen Bilimleri Enstitüsü, Karabük, (2013).

23. Verma, P., Zare, A., Jafari, M., Bodisco, T.A., Rainey, T., Ristovski, Z.D., Brown, R.J., Diesel engine performance and emissions with fuels derived from waste tyres. Nature Research Journals, 8:2457, (2018).

24. Bhimani, S., Alvarado, J.L., Annamalai, K., Marsh, C., Emission characteristics of methanol-in-canola oil emulsions in a combustion chamber, Fuel, 113: 97-106, (2013). 25. Nadeem, M., Rangkuti, C., Anuar, K., Haq, M.R.U., Tan, I.B., Shah, S.S., Diesel engine performance and emission evaluation using emulsified fuels stabilized by conventional and gemini surfactants. Fuel. 85: 2111-2119, (2006).

26. Alçelik, N., Atik yağlardan üretilen biyodizelin tek silindirli bir dizel motorun performans, egzoz emisyonlari ve titreşimine olan etkilerinin incelenmesi. Yüksek Lisans Tezi. Düzce Üniversitesi, Fen Bilimleri Enstitüsü, Düzce, (2017).

27. Kalargaris, I., Tian, G., Gu, S., Combustion, performance and emission analysis of a DI diesel engine using plastic pyrolysis oil. Fuel Processing Technology, 157: 108-115, (2017). 